sons for the erratic appearances of the Black Duck in Saskatchewan in the past, naturalists will welcome a chance to follow any new reports hoping now, in the light of recent research, to be able to discover some of the causes. Our hunters will welcome reports cf the Black Duck's return for it is considered, by some, to be the "wildest," the most sagacious and wary of ducks. Our bird watchers, anxious to add this eastern bird to their lists, will eagerly scan each flock of Mallards hoping to see some Black Ducks. Such identifications should not be difficult. It is a large brown duck, appearing black at a distance, and easily distinguished from our cther sooty-coloured ducks, the Scoters, by its light streaked neck and head, its mallard bill, and the silvery white lining of its wings.

\title{
American Avocets Nesting at Oak Lake, Manitoba
}

\author{
By David Hatch, Oak Lake, Man.
}

EDITOR'S NOTE: David Hatch, at sixteen years of age, is an ardent bird watcher, and we welcome his contribution to the regular columns of the Blue Jay. Another young contributor who is a very keen bindman is Bill Horseman, of Saltcoats. Two pictures of hawks that he took this year appear on page 114 .

Plum Creek was dredged three years ago but no dam was built on it until mid July of this year. Because of this and also because we have had a dry summer, the famed Oak Lake marshes have dried up to such an extent that acres and acres of bare mudflats exist. This has resulted in some rare birds moving into this area. One of these, the most striking shorebird I have ever seen, is the American Avocet.

Up to 1957 I had never seen American Avocets, but that year a pair nested in the Oak Lake Marsh. This was the only American Avocet record for Manitoba that year. Although Mr. Herman Battersby, my birding companion, and I did look thoroughly for the nest we couldn't find it. When we were looking for the nest the pair would fly around dive-bombing us iust as Tree Swallows do when you are close to their nest. They also used the broken-wing act of the Killdeer.

By the end of May, 1958, fourteen Avocets were in this area. On June 23 two nests were found on the bare mudflat; one was about ten yards from the nearest rushes, the other was about 100 yards. The nest was a slight depression in the mud lined with about thirty coarse rushes two to three inches in length. One contained four eggs, the other three young and one egg. The large, sharply-pointed, clay-coloured eggs are blotched with black and have the odd pale blue spot. They are larger than a Killdeer's egg, but smaller than a Mallard Duck's. Like the plover's eggs, they have all their small ends pointing inward in the nest.

The downy young are web-footed. They would run quickly to the water and swim away from us. They are slightly tinged with rust ard when they sat still on the mud they were perfectly camouflaged.

Mr. Eddy Giggens took about twenty feet of film and both $\mathrm{Mr}$. Battersby and I took pictures with our cameras.

It is to be hoped that these magnificent birds will thrive in this area and will increase in number across the continent.

\section{MAMMALS OF SASKATCHEWAN}

We are pleased to announce that Harvey Beck's bulletin on the mammals of Saskatchewan is now being printed. As soon as it comes from the printers the bulletin will be mailed to those who have already written for a copy. The price of the Mammals of Saskatchewan is fifty cents. Order from E. L. Fox, 1053 Gladmer Park, Regina. 